\title{
Lack of genotoxicity in Astyanax bimaculatus and Oreochromis niloticus of 17a-methyltestosterone used in fish hatcheries to produce male monosex populations
}

\author{
C.L.G. Rivero-Wendt ${ }^{1}$, A.L. Miranda-Vilela ${ }^{1}$, M.F.N. Ferreira ${ }^{1}$, \\ F.S. Amorim ${ }^{2}$, V.A.G. da Silva ${ }^{2}$, H. Louvandini ${ }^{3}$ and C.K. Grisolia ${ }^{1}$ \\ ${ }^{1}$ Departamento de Genética e Morfologia, Instituto de Ciências Biológicas, \\ Universidade de Brasília, Brasília, DF, Brasil \\ ${ }^{2}$ Laboratório de Química Analítica Ambiental, Instituto de Química, \\ Universidade de Brasília, Brasília, DF, Brasil \\ ${ }^{3}$ Centro de Energia Nuclear na Agricultura, Escola Superior de Agricultura \\ "Luiz de Queiroz", Universidade de São Paulo, Piracicaba, SP, Brasil \\ Corresponding author: C.K. Grisolia \\ E-mail: grisolia@unb.br
}

Genet. Mol. Res. 12 (4): 5013-5022 (2013)

Received June 25, 2013

Accepted September 18, 2013

Published October 24, 2013

DOI http://dx.doi.org/10.4238/2013.October.24.14

\begin{abstract}
Methyltestosterone (MT) is widely used in fish hatcheries of many countries to produce male monosex populations. Its genotoxic risk to fish species is not well known and studies in other in vivo models are still inconclusive. MT was tested for genotoxicity in the fish species Oreochromis niloticus (tilapia), a target species, and Astyanax bimaculatus (lambari), a native non-target species. Genotoxicity was evaluated by the micronucleus test (MN), nuclear abnormalities (NA), and comet assay using peripheral erythrocytes of both species after a 96-h exposure to MT at concentrations of 0.01 , 0.1 , and $1.0 \mathrm{mg} / \mathrm{L}$ in the water. At the lowest exposure level of 0.01
\end{abstract}


$\mathrm{mg} / \mathrm{L}, \mathrm{MT}$ induced $\mathrm{MN}$ in both species and NA only in $O$. niloticus. These effects were not observed in the comet assay. Chromatographic analysis of water samples collected from aquariums at the beginning and end of each experiment showed that MT was consumed during the 96-h exposure. At the highest level of exposure $(1.0 \mathrm{mg} / \mathrm{L})$, $81.69 \%$ of the hormone was consumed during the exposure period. The chromatogram showed that at the lowest concentration level of $0.01 \mathrm{mg} / \mathrm{L}, 99.56 \%$ MT was consumed by the end of the exposure period. Thus, exposure to MT did not cause genotoxicity in either fish species.

Key words: Fish micronucleus; Comet assay; Endocrine disruptors; Fish hatcheries

\section{INTRODUCTION}

$17 \alpha$-Methyltestosterone (MT) is a synthetic hormone widely used as a reference chemical in fish hatcheries to induce sex reversal, producing male monosex populations, since this practice is economically more viable (Pandian and Sheela, 1995). MT is considered an endocrine disruptor in fish, causing physiological and developmental abnormalities such as increasing vitellogenin concentrations and gonadal intersexuality in male fish (Zerulla et al., 2002). There is concern about and resistance to the use of hormones in food production, and more efforts could be made to know how androgenic chemicals used in aquaculture can adversely affect wildlife, fish reproduction and food production. The androgenic effects of environmental endocrine disruptor chemicals (EDC) on aquatic organisms have received increased attention, particularly with respect to fish, since they are the target of chemicals such as these to induce sex reversal (Papoulias et al., 2000).

Few studies have been reported assessing the possible genotoxic effect of MT or on any aspect of DNA damage caused by testosterone exposure in target and non-target fish species. Sex steroid hormones are considered non-genotoxic carcinogens, but controversial results have been reported regarding this subject (Hana et al., 2008). In a study using microarray technology to evaluate the effects of EDCs on Cyprinus carpio gene expression, it was observed that MT induced expression in a group of genes such as serum lectin, interleukin 2 , and vitellogenin, which are associated with immune response, lipid transport, and oogenesis, respectively (Moens et al., 2006). A literature review by Joosten et al. (2004) showed that testosterone and its esters, and methylnortestosterone as well, are not mutagenic in bacteria. The anabolics trenbolone, fluoxymesterone, and oxymetholone have been found to be negative in bacterial and mammalian cell systems.

In fish, the combination of micronucleus test (MN), nuclear abnormality test (NA), and the comet assay can be carried out in the same organism to give more consistency to in vivo evaluation of the genotoxicity of environmental pollutants (al-Sabti and Metcalfe, 1995; Grisolia and Starling, 2001; Pacheco and Santos, 2002; Kim and Hyun, 2006; Bolognesi et al., 2006; Grisolia et al., 2009). In this study, Oreochromis niloticus, a target species for MT in fish hatcheries, and Astyanax bimaculatus, a non-target species for MT in hatcheries, were exposed to MT, to evaluate its possible genotoxicity. This genotoxic assessment 
was performed, using these three endpoints simultaneously, in the peripheral erythrocytes of both fish species.

\section{MATERIAL AND METHODS}

\section{Chemical test}

MT, 90\% purity, was purchased from Bioativa Pharmacy (Paraná, Brazil), which is commonly used in Brazilian aquaculture dissolved in fish chow. As MT is insoluble in water, it was dissolved in $0.05 \mathrm{~mL}$ absolute ethanol and then diluted in water to give the final concentrations of $0.01,0.1$, and $1.0 \mathrm{mg} / \mathrm{L}$.

\section{Determination of MT in aquarium water}

Samples of $50 \mathrm{~mL}$ water were collected from aquariums at the beginning and end of each experiment and stored in a refrigerator at $4^{\circ} \mathrm{C}$. The analytical method used was an adaptation of Falone (2007) for analysis of MT in water samples and sediments from fish hatcheries. Solid phase extraction was carried out using cartridges with silica gel as the stationary phase with chemically bonded nonpolar organic group $\mathrm{C} 18$. The cartridges of polypropylene syringes (AccuBondII-Agilent Technologies) contained $1000 \mathrm{mg}$ stationary phase and had a volume of $6 \mathrm{~mL}$. Conditions of solid phase extraction were: C18-cartridge methanol/water $(1: 1, \mathrm{v} / \mathrm{v})$; ethanol as solvent for eluting the analyte; $5 \mathrm{~mL}$ solvent for extraction; final volume of $3 \mathrm{~mL}$ containing the analyte. Chromatographic analysis was then carried out: after performing extraction of water samples, high-performance liquid chromatography was used as an analytical technique for the quantification of the MT hormone (Perkin Elmer series 200). Chromatographic conditions were: detector UV-Vis, C18octadecylsilane, flow rate of $0.4 \mathrm{~mL} / \mathrm{min}$, wavelength of $236 \mathrm{~nm}$, injected volume of 20 $\mu \mathrm{L}$. Mobile phase was methanol/water 80:20 (v/v), isocratic mode. Retention time was 11.6 min at room temperature.

\section{Experimental design}

$O$. niloticus and $A$. bimaculatus were obtained from a fish hatcherie in the local municipality, where breeding and health conditions were controlled and monitored constantly. The criterion for fish selection was body length of 7-10 cm for O. niloticus and 9-12 $\mathrm{cm}$ for A. bimaculatus. Fish were acclimatized in Laboratório de Toxicologia Genética at Universidade de Brasília, Brazil, for 2 weeks in 250-L tanks, with continuously aerated filtered and dechlorinated tapwater. They were maintained at a constant temperature of $26^{\circ}$ $\pm 2^{\circ} \mathrm{C}$ and fed ad libitum with fish chow, based on soybean protein. The ammonium level in the water was constantly monitored, and conductivity and $\mathrm{pH}$ were kept at $500 \mathrm{mS}$ and 7.2, respectively. Groups of $10 \mathrm{O}$. niloticus and $10 \mathrm{~A}$. bimaculatus were exposed for $96 \mathrm{~h}$ (OECD , 1992) in a glass aquarium of $30 \mathrm{~L}$ as follows: control group, ethanol control group at $0.05 \mathrm{~mL} / \mathrm{L}$, and $0.01,0.1$, and $1.0 \mathrm{mg} / \mathrm{L} \mathrm{MT}$ groups. The exposure concentrations were chosen on the basis of the amount of hormone used daily in fish hatchery tanks. Experiments were carried out in duplicate, 10 fish per replicate. Peripheral blood was obtained by cardiac 
puncture with a heparinized syringe, from which smears were immediately prepared for the $\mathrm{MN}$ and NA counts, and $50 \mu \mathrm{L}$ was collected for the comet assay.

\section{MN and NA tests}

For each treatment, all 10 fish were sampled and 3000 erythrocytes with complete cytoplasm were scored per fish (total of 30,000 cells per treatment). Slides were stained with Giemsa and analyzed at a magnification of $1000 \mathrm{X}$, to score MN and NA. The criteria for the identification of fish micronucleated erythrocytes were as follows: a) MN should be smaller than one-third of the main nucleus; b) MN must not touch the main nucleus; c) MN must be of the same color and intensity as the main nucleus. NAs were classified as blebbed, lobed, notched, and binucleated (Hooftman and Raat, 1982).

\section{Comet assay}

This assay was performed as described by Singh et al. (1988), with some modifications for fish as previously reported by Rivero et al. (2008), as described below. The cell suspension sampled in the microtubule was mixed with $120 \mu \mathrm{L}$ low melting agarose $\left(37^{\circ} \mathrm{C}\right)$. Next, $500 \mu \mathrm{L}$ erythrocyte-agarose suspension was placed on a fully frosted slide pre-coated with standard agarose (1.5\%) and covered with a coverslip. The slides were then placed on ice for $15 \mathrm{~min}$ to allow complete agarose polymerization and afterwards in a chilled lysing solution (2.5 M NaCl, $100 \mathrm{mM}$ EDTA, $10 \mathrm{mM}$ Tris, $1 \%$ N-laurolyl-sarcosine, $1 \%$ Triton-X, $10 \% \mathrm{DMSO}, \mathrm{pH} \mathrm{10}$ ) for at least $1 \mathrm{~h}$, required for cell membrane rupture, thus exposing the genetic material for analysis. The slides were then placed on a horizontal gel electrophoresis platform and covered with a chilled alkaline solution consisting of $300 \mathrm{mM} \mathrm{NaOH}$ and $1 \mathrm{mM} \mathrm{Na}{ }_{2}$ EDTA, pH 13, and left in the dark at $4^{\circ} \mathrm{C}$ for $30 \mathrm{~min}$. DNA was electrophoresed at $4^{\circ} \mathrm{C}$ in the dark for $30 \mathrm{~min}$ at $25 \mathrm{~V}$ and approximately $350 \mathrm{~mA}$. The slides were gently rinsed twice with $400 \mathrm{mM}$ Tris, $\mathrm{pH} 7.5$, to neutralize the alkali. Each slide was stained with $30 \mu \mathrm{L} 20 \mu \mathrm{g} / \mathrm{mL}$ ethidium bromide and covered with a coverslip. One hundred cells from each replicate were randomly chosen ( 50 from each duplicate slide), and analyzed under a fluorescence microscope (Axioskop-2, Carl Zeiss), with a 510-560-nm filter and a 590-nm barrier filter, with a magnification of 400X. For index of damage (ID) calculation, cells were sorted into four classes, according to tail size. The ID is the sum of classes of the 100 cells analyzed per fish, and may vary from 0 (all cells undamaged $=0 \times 100$ ) to 400 (all cells highly damaged $=4 \times 100$ ). The ID is based on the length of migration and on the amount of DNA in the tail, and it is considered to be a sensitive measurement of detectable DNA damage.

\section{Statistical analysis}

Statistical analysis was carried out using SPSS (Statistical Package for the Social Sciences) version 15.0. Data are reported as means $\pm \mathrm{SE}$ (standard error) and $\mathrm{P}<0.05$ was considered to be statistically significant. The continuous variables were tested for normal distribution with the Shapiro-Wilk test. Possible differences between the groups were inves- 
tigated by ANOVA or the Kruskal-Wallis test (when the data were not normally distributed), followed respectively by the Bonferroni test or the Mann-Whitney U-test to carry out 2-by-2 comparisons.

\section{RESULTS}

MT did not induce $\mathrm{MN}$ in $O$. niloticus at the higher concentrations of 0.1 and 1.0 $\mathrm{mg} / \mathrm{L}$. However, at the lowest concentration of $0.01 \mathrm{mg} / \mathrm{L}$, an increased level of MN was observed $(\mathrm{P}<0.05)$ compared with both control groups. Regarding the results for NA, exposures at 0.01 and $1.0 \mathrm{mg} / \mathrm{L}$ were statistically significant when compared only with the ethanol control group. The level of NA in the ethanol control group was lower than in the water control, showing that ethanol did not have an influence on the observed results of MT exposure (Table 1). In the CA, MT did not induce DNA damage at the three exposure levels. The ethanol control groups showed no DNA damage. In A. bimaculatus, MT did not induce DNA damage or NA. However, at the lowest concentration of $0.01 \mathrm{mg} / \mathrm{L}$, an increased level of MN was observed $(\mathrm{P}<0.05)$ compared with both control groups (Table 2$)$.

Table 1. Results of micronucleus (MN), nuclear abnormality (NA), and comet assays after a 96-h exposure of
Oreochromis niloticus to $17 \alpha$-methyltestosterone.
\begin{tabular}{lccccc}
\hline Group & Fish & Treatment & MN/3000 cells & NA/1000 cells & DNA damage \\
\hline 1 & 10 & Control & $0.10 \pm 0.10^{\mathrm{a}}$ & $5.00 \pm 1.42^{\mathrm{a}}$ & $61.00 \pm 3.96$ \\
2 & 10 & Ethanol & $0.09 \pm 0.09^{\mathrm{c}}$ & $0.73 \pm 0.63^{\mathrm{b}, \mathrm{c}}$ & $68.50 \pm 3.70$ \\
3 & 10 & $0.01 \mathrm{mg} / \mathrm{L}$ & $1.43 \pm 0.53^{\mathrm{b}, \mathrm{d}, \mathrm{e}}$ & $12.43 \pm 4.55^{\mathrm{d}}$ & $59.14 \pm 6.73$ \\
4 & 10 & $0.1 \mathrm{mg} / \mathrm{L}$ & $0.63 \pm 0.26^{\mathrm{d}}$ & $7.88 \pm 3.50$ & $69.56 \pm 6.68$ \\
5 & 10 & $1.0 \mathrm{mg} / \mathrm{L}$ & $0.25 \pm 0.16^{\mathrm{f}}$ & $11.13 \pm 4.84^{\mathrm{d}}$ & $79.79 \pm 2.31$ \\
& & P values & 0.010 & 0.003 & 0.043 \\
\hline
\end{tabular}

Data are reported as means \pm standard error. $\mathrm{P}$ values were generated by the Kruskall-Wallis test. The lowercase letters indicate significant differences detected by the Mann-Whitney test in 2-by-2 comparisons $(a \neq b ; c \neq d ; e \neq f)$.

Table 2. Results of micronucleus (MN), nuclear abnormality (NA), and comet assays after a 96-h exposure of Astyanax bimaculatus to $17 \alpha$-methyltestosterone.

\begin{tabular}{lclcrr}
\hline Group & Fish & Treatment & MN/3000 cells & NA/1000 cells & DNA damage \\
\hline 1 & 10 & Control & $0.22 \pm 0.09^{\mathrm{a}}$ & $2.70 \pm 0.83$ & $59.18 \pm 5.73$ \\
2 & 10 & Ethanol & $0.81 \pm 0.31^{\mathrm{c}}$ & $3.71 \pm 0.71$ & $43.05 \pm 6.67$ \\
3 & 10 & $0.01 \mathrm{mg} / \mathrm{L}$ & $2.25 \pm 0.50^{\mathrm{b}, \mathrm{d}, \mathrm{e}}$ & $2.30 \pm 0.83$ & $62.88 \pm 5.04$ \\
4 & 10 & $0.1 \mathrm{mg} / \mathrm{L}$ & $0.00 \pm 0.00^{\mathrm{b}, \mathrm{fg}}$ & $1.94 \pm 0.60$ & $74.10 \pm 3.36$ \\
5 & 10 & $1.0 \mathrm{mg} / \mathrm{L}$ & $0.56 \pm 0.22^{\mathrm{f}, \mathrm{h}}$ & $3.38 \pm 0.75$ & $72.23 \pm 6.22$ \\
& & P values & 0.000 & 0.162 & 0.011 \\
\hline
\end{tabular}

Data are reported as means \pm standard error. $\mathrm{P}$ values were generated by the Kruskall-Wallis test. The lowercase letters indicate significant differences detected by the Mann-Whitney test in the 2-by-2 comparisons $(\mathrm{a} \neq \mathrm{b} ; \mathrm{c} \neq \mathrm{d}$; $\mathrm{e} \neq \mathrm{f}$ ).

Chromatographic analyses of water samples collected from aquariums at the beginning and end of each experiment showed that at the lowest concentration level of $0.01 \mathrm{mg} / \mathrm{L}$, 99.56\% MT was consumed (Figure 1), while at the highest level of exposure $(1.0 \mathrm{mg} / \mathrm{L})$, $81.69 \%$ hormone was consumed (Figure 2) during the exposure period of $96 \mathrm{~h}$. 

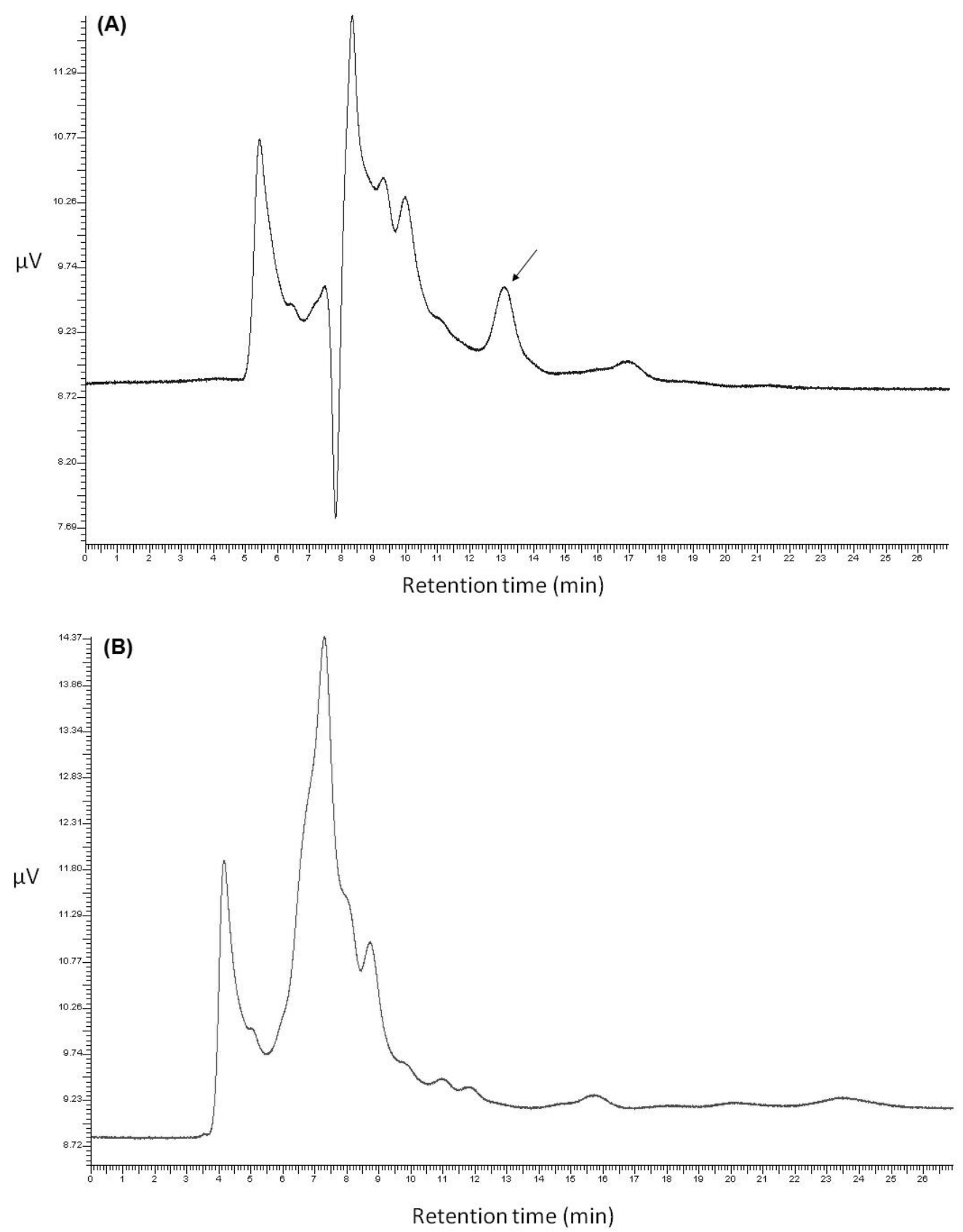

Figure 1. Chromatogram of aquarium water samples of group $3(0.01 \mathrm{mg} / \mathrm{L})$, taken at the beginning of exposure (A) and after a 96-h exposure (B). There was a consumption of $99.56 \%$ of the hormone in the period of $96 \mathrm{~h}$. Arrow shows the peak of $17 \alpha$-methyltestosterone at retention time between 12 and $13 \mathrm{~min}$. 

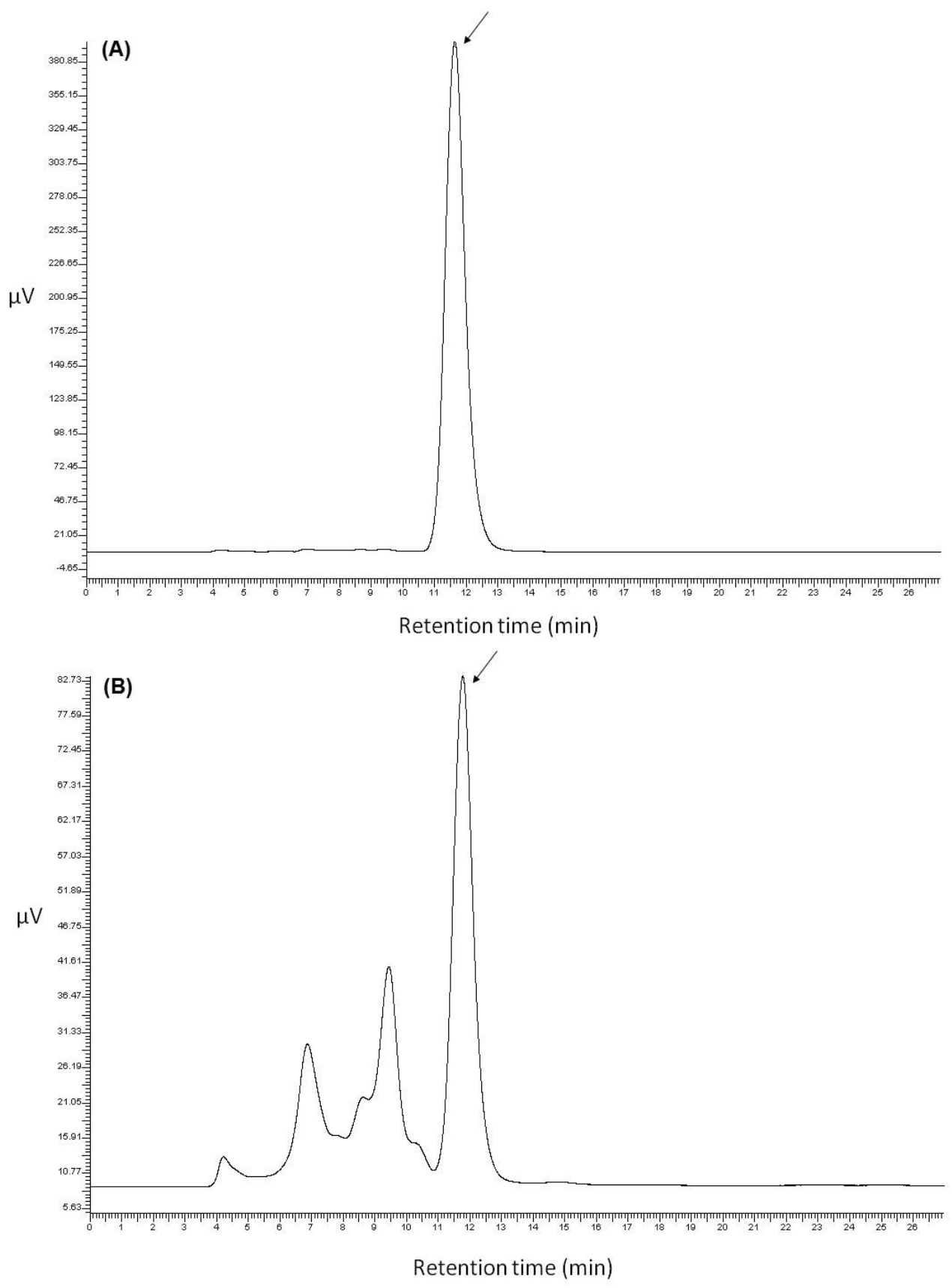

Figure 2. Chromatogram of aquarium water samples of group $5(1.0 \mathrm{mg} / \mathrm{L})$, taken at the beginning of exposure (A) and after a 96 -h exposure (B). There was a consumption of $81.69 \%$ of the hormone in the period of $96 \mathrm{~h}$. Arrow shows the peak of $17 \alpha$-methyltestosterone at retention time between 12 and $13 \mathrm{~min}$. 


\section{DISCUSSION}

The genotoxic profile of several androgenic synthetic steroids on male mouse chromosomes has been evaluated, showing that testosterone, pyridoandrostene, and its derivatives do not induce chromosomal aberrations. However, pyrimidinoandrostene, at both low and high doses, causes a significant increase in the mean value of chromosomal aberrations, showing that synthesized heterocyclic steroid androgens could be investigated for their possible genotoxic effects (Hana et al., 2008). The effects of MT on chromosomal synapsis in O. niloticus exposed orally at $50 \mathrm{mg} / \mathrm{kg}$ for 30 days have been also examined and MT did not significantly alter the pattern of the synaptonemal complex, or number and morphology of chromosomes (Carrasco et al., 1999). In our study, a low exposure concentration of 0.01 $\mathrm{mg} / \mathrm{L}$ showed a weak genotoxic potential, where $\mathrm{MN}$ was induced in both species as well as NA only in O. niloticus; these effects were not observed in comet assay. Comet assay has been successfully applied under laboratory and field conditions as a non-specific, sensitive, rapid, and economical bioassay for the evaluation of genetic damage in natural biota (Jha, 2008), also suggesting that comet assay is a suitable bioassay for detecting oxidized DNA bases in fish exposed to environmental oxidative stressors. Our comet assay results showed that MT was not genotoxic, meaning that it did not induce DNA damage at the 3 exposure levels in either species. The MN test in fish peripheral erythrocytes is a suitable genetic bioassay for detecting mutagens in the aquatic environment. Since erythrocytes in teleost fish are nucleated cells, scoring $\mathrm{MN}$ as an endpoint of genotoxicity has been widely used. Thus, many studies in the literature have shown MN induction after exposure to different water pollutants under field and laboratory conditions (Hooftman and Raat, 1982; al-Sabti and Metcalfe, 1995; da Silva et al., 2011). Disturbances in the DNA molecule such as adducts, single, and double-strand breaks may cause permanent damage that induces MN, being then an excellent biomarker to evaluate any permanent DNA damage (Vanzella et al., 2007). Increased MN frequencies in blood cells of the Neotropical fish Prochilodus lineatus exposed to diesel water soluble fraction under acute and subchronic conditions, demonstrated that $\mathrm{MN}$ is an efficient endpoint for detecting mutagenic compounds in water (Simoniello et al., 2009).

Sex steroid hormones generally respond negatively to standard genotoxicity assays, but are considered to be epigenetic carcinogens because they can modify gene expression (Martelli et al., 2003). Petridis et al. (2009) evaluated the genotoxicity of estradiol, ethinylestradiol, and nonylphenol using comet assay in Scrobicularia plana, an estuarine clam. They found a genotoxic effect only at the highest exposure level. Exposure to MT at a low concentration may cause a direct stimulation of the receptor pathway, following its activation, and consequently cell disturbances. This could explain the results obtained in our study, where only the lowest concentration showed potential for genotoxicity compared to higher concentrations (Calabrese and Mattson, 2011). On the other hand, due to its rapid degradation in water, organisms are exposed only to low concentrations. As there was no dose-response effect, we suspect that MT has a low risk of genotoxicity. The ethanol amount used did not exceed $0.001 \%$ in the water and we observed that it did not interfere with the results. In field situations, pollutants dissolved or suspended in the water require an appropriate native species as an in situ bioindicator. A. bimaculatus, a native potamodromous fish species, commonly known as 'lambari', is widely abundant throughout South America. The species, besides playing a central role in riverine food webs, is sensitive to environmental degradation. These characteristics make it 
an excellent bioindicator, commonly present in Brazilian ponds and rivers, where it is a nontarget potential of this androgen (da Silva et al., 2010). In our previous study, A. bimaculatus and $O$. niloticus were exposed for 28 days through food containing MT $(60 \mathrm{mg} / \mathrm{L})$, as normally occurs in fish hatcheries. There were no significant increases in MN frequency or comet induction in either species (Rivero-Wendt et al., 2013).

Fish hatchery units in which fish are fed with MT-treated chow may exert environmental impacts when water is discharged. In a study in which sexually undifferentiated tilapias were fed radiolabeled $\left[{ }^{3} \mathrm{H}\right]-\mathrm{MT}$ for 30 days, and blood samples were drawn 10 days later, only trace amounts of $\left[{ }^{3} \mathrm{H}\right]$-MT metabolites were detected. Remaining radioactivity was located mainly in the liver. Normally, tilapias are marketed as gutted fish or as fillets (Goudie et al., 1986; Curtis et al., 1991; Green and Teichert-Coddington, 2000). Unmetabolized androgen and its metabolites may accumulate in water, affecting non-target fish species. MT and metabolites discharged into receiving waters are expected to biotransform. Evidence for this transformation was present in our chromatographic studies, showing that in a period of $96 \mathrm{~h}$ MT was almost completely degraded under laboratory conditions, comparing the peaks in chromatograms A and B. Degradation of MT under natural conditions is expected to be faster due to bacterial decomposition and photodegradation by sunlight. Currently, MT is not approved for use in Brazilian fish hatcheries to produce male monosex populations. Considering that MT induced MN only at the lower exposure level of $0.01 \mathrm{mg} / \mathrm{L}$ in both species, as well as NA only in $O$. niloticus, and did not induce comets, we concluded that this compound has a low genotoxic risk. Chromatographic analysis of water samples collected from aquariums at the beginning and end of each experiment showed that at the lowest concentration level of $0.01 \mathrm{mg} / \mathrm{L}$, MT was $99.56 \%$ consumed, while at the highest level of exposure $(1.0 \mathrm{mg} / \mathrm{L})$, $81.69 \%$ hormone was consumed during the exposure period of $96 \mathrm{~h}$. In conclusion, these results suggest that MT does not show genotoxicity in either fish species and that this hormone in water samples has a high rate of consumption/degradation, thus being available only at a very low concentration and for a short time.

\section{ACKNOWLEDGMENTS}

Research supported by Conselho Nacional de Desenvolvimento Científico e Tecnológico (CNPq, \#578541/2008-4), and the Universidade de Brasília. C.L.G. Rivero-Wendt, F.S. Amorim, and V.A.G. da Silva received a fellowship from CNPq, and Ana Luisa Miranda-Vilela was awarded a postdoctoral fellowship from the Brazilian Ministry of Education (CAPES-Rede CON-NANO).

\section{REFERENCES}

al-Sabti K and Metcalfe CD (1995). Fish micronuclei for assessing genotoxicity in water. Mutat. Res. 343: 121-135.

Bolognesi C, Perrone E, Roggieri P, Pampanin DM, et al. (2006). Assessment of micronuclei induction in peripheral erythrocytes of fish exposed to xenobiotics under controlled conditions. Aquat. Toxicol. 78 Suppl 1: S93-S98.

Calabrese EJ and Mattson MP (2011). Hormesis provides a generalized quantitative estimate of biological plasticity. $J$. Cell Commun. Signal. 5: 25-38.

Carrasco LA, Penman DJ, Villalobos SA and Bromage N (1999). The effects of oral administration with 17 alphamethyltestosterone on chromosomal synapsis in Oreochromis niloticus (Pisces, Cichlidae). Mutat. Res. 430: 87-98.

Curtis LR, Diren FT, Hurley MD, Seim WK, et al. (1991). Disposition and elimination of 17 $\alpha$-methyltestosterone in Nile tilapia (Oreochromis niloticus). Aquaculture 99: 193-201. 
da Silva RR, Pires OR Jr. and Grisolia CK (2010). Toxicity and genotoxicity in Astyanax bimaculatus (Characidae) induced by microcystins from a bloom of Microcystis spp. Genet. Mol. Biol. 33: 750-755.

da Silva RR, Pires OR and Grisolia CK (2011). Genotoxicity in Oreochromis niloticus (Cichlidae) induced by Microcystis spp bloom extract containing microcystins. Toxicon 58: 259-264.

Falone SZ (2007). Desenvolvimento de Métodos para a Determinação do Hormônio 17-alfa-Metiltestosterona em Amostras de Água e de Sedimentos de Piscicultura: Ensaios Ecotoxicológicos com Cladóceros. Doctoral thesis, Ciências da Engenharia Ambiental, Universidade de São Paulo, São Carlos, 155.

Goudie CA, Shelton WL and Parker NC (1986). Tissue distribution and elimination of radiolabelled methyltestosterone fed to adult blue tilapia. Aquaculture 58: 227-240.

Green BW and Teichert-Coddington DR (2000). Human food safety and environmental assessment of the use of 17 $\alpha$-methyltestosterone to produce male tilapia in the United States. J. World Aquaculture Soc. 31: 337-357.

Grisolia CK and Starling FL (2001). Micronuclei monitoring of fishes from Lake Paranoá, under influence of sewage treatment plant discharges. Mutat. Res. 491: 39-44.

Grisolia CK, Rivero CL, Starling FL, da Silva IC, et al. (2009). Profile of micronucleus frequencies and DNA damage in different species of fish in a eutrophic tropical lake. Genet. Mol. Biol. 32: 138-143.

Hana HY, Khalil WK, Elmakawy AI and Elmegeed GA (2008). Androgenic profile and genotoxicity evaluation of testosterone propionate and novel synthesized heterocyclic steroids. J. Steroid Biochem. Mol. Biol. 110: 284-294.

Hooftman RN and de Raat WK (1982). Induction of nuclear anomalies (micronuclei) in the peripheral blood erythrocytes of the eastern mudminnow Umbra pygmaea by ethyl methanesulphonate. Mutat. Res. 104: 147-152.

Jha AN (2008). Ecotoxicological applications and significance of the comet assay. Mutagenesis 23: 207-221.

Joosten HF, van Acker FA, van den Dobbelsteen DJ, Horbach GJ, et al. (2004). Genotoxicity of hormonal steroids. Toxicol. Lett. 151: 113-134.

Kim IY and Hyun CK (2006). Comparative evaluation of the alkaline comet assay with the micronucleus test for genotoxicity monitoring using aquatic organisms. Ecotoxicol. Environ. Saf. 64: 288-297.

Martelli A, Mattioli F, Angiola M, Reimann R, et al. (2003). Species, sex and inter-individual differences in DNA repair induced by nine sex steroids in primary cultures of rat and human hepatocytes. Mutat. Res. 536: 69-78.

Moens LN, van der Ven K, van Remortel P, Del-Favero J, et al. (2006). Expression profiling of endocrine-disrupting compounds using a customized Cyprinus carpio cDNA microarray. Toxicol. Sci. 93: 298-310.

OECD (1992). Test No 203: Fish Acute Toxicity Test. Organization for Economic Co-Operation and Development, Paris.

Pacheco M and Santos MA (2002). Biotransformation, genotoxic, and histopathological effects of environmental contaminants in European eel (Anguilla anguilla L.). Ecotoxicol. Environ. Saf. 53: 331-347.

Pandian TJ and Sheela SG (1995). Hormonal induction of sex reversal in fish. Aquaculture 138: 1-22.

Papoulias DM, Noltie DB and Tillitt DE (2000). Effects of methyl testosterone exposure on sexual differentiation in medaka, Oryzias latipes. Mar. Environ. Res. 50: 181-184.

Petridis P, Jha AN and Langston WJ (2009). Measurements of the genotoxic potential of (xeno-)oestrogens in the bivalve mollusc Scrobicularia plana, using the comet assay. Aquat. Toxicol. 94: 8-15.

Rivero-Wendt CLG, Miranda-Vilela NA, Ferreira MFN, Borges AB, et al. (2013). Cytogenetic toxicity and gonadal effects of $17 \alpha$-methyltestosterone in Astyanax bimaculatus (Characidae) and Oreochromis niloticus (Cichlidae). Genet. Mol. Res. 12: 3862-3870.

Rivero CL, Barbosa AC, Ferreira MF, Dorea JG, et al. (2008). Evaluation of genotoxicity and effects on reproduction of nonylphenol in Oreochromis niloticus (Pisces: Cichlidae). Ecotoxicology 17: 732-737.

Simoniello MF, Gigena F, Poletta G, Loteste A, et al. (2009). Alkaline comet assay for genotoxic effect detection in neotropical fish Prochilodus lineatus (Pisces, Curimatidae). Bull. Environ. Contam. Toxicol. 83: 155-158.

Singh NP, McCoy MT, Tice RR and Schneider EL (1988). A simple technique for quantitation of low levels of DNA damage in individual cells. Exp. Cell Res. 175: 184-191.

Vanzella TP, Martinez CB and Cólus IM (2007). Genotoxic and mutagenic effects of diesel oil water soluble fraction on a neotropical fish species. Mutat. Res. 631: 36-43.

Zerulla M, Länge R, Steger-Hartmann T, Panter G, et al. (2002). Morphological sex reversal upon short-term exposure to endocrine modulators in juvenile fathead minnow (Pimephales promelas). Toxicol. Lett. 131: 51-63. 